\title{
nSESARCANS S \\ PHYSICALL \\ Bovine colostrum supplementation enhances sensitivity of the in vivo immune response to a novel antigen following prolonged exercise
}
Autor(es):
Davison, Glen; Jones, Arwel Wyn; March, Daniel Scott; Thatcher, Rhys;
Diment, Bethany Claire; Walsh, Neil Peter

Publicado por: Imprensa da Universidade de Coimbra

URL

persistente:

URI:http://hdl.handle.net/10316.2/44101

DOI:

DOI:https://doi.org/10.14195/2182-7087_ex2018_38

Accessed : $\quad$ 26-Apr-2023 00:33:41

A navegação consulta e descarregamento dos títulos inseridos nas Bibliotecas Digitais UC Digitalis, UC Pombalina e UC Impactum, pressupõem a aceitação plena e sem reservas dos Termos e Condições de Uso destas Bibliotecas Digitais, disponíveis em https://digitalis.uc.pt/pt-pt/termos.

Conforme exposto nos referidos Termos e Condições de Uso, o descarregamento de títulos de acesso restrito requer uma licença válida de autorização devendo o utilizador aceder ao(s) documento(s) a partir de um endereço de IP da instituição detentora da supramencionada licença.

Ao utilizador é apenas permitido o descarregamento para uso pessoal, pelo que o emprego do(s) título(s) descarregado(s) para outro fim, designadamente comercial, carece de autorização do respetivo autor ou editor da obra.

Na medida em que todas as obras da UC Digitalis se encontram protegidas pelo Código do Direito de Autor e Direitos Conexos e demais legislação aplicável, toda a cópia, parcial ou total, deste documento, nos casos em que é legalmente admitida, deverá conter ou fazer-se acompanhar por este aviso. 


\section{ANNALS OF RESEARCH IN SPORT AND PHYSICAL ACTIVITY}




\section{BOVINE COLOSTRUM SUPPLEMENTATION ENHANCES SENSITIVITY OF THE IN VIVO IMMUNE RESPONSE TO A NOVEL ANTIGEN FOLLOWING PROLONGED EXERCISE}

Glen Davison; Arwel Wyn Jones²; Daniel Scott March³; Rhys Thatcher4; Bethany Claire Diment $^{5}$; Neil Peter Walsh ${ }^{6}$

\section{INTRODUCTION}

Prolonged exercise significantly reduces both the induction and elicitation of in vivo cellmediated immune responses. The aim of the present study was to determine the effect of supplementation with bovine colostrum on in vivo immune induction using experimental contact hypersensitivity with the novel antigen DPCP.

\section{METHODS}

In a double-blind design, 31 males were randomly assigned to either bovine colostrum $\left(\mathrm{COL}, 20 \mathrm{~g} /\right.$ day, $\mathrm{n}=15$, age $23 \pm 5$ years, $\mathrm{VO}_{2}$ max: $57 \pm 8 \mathrm{~mL} \cdot \mathrm{kg}^{-1} \cdot \mathrm{min}^{-1}$ ) or placebo $(\mathrm{PLA}, \mathrm{n}$ $=16$, age $25 \pm 6$ years, $\left.\mathrm{VO}_{2} \max 56 \pm 5 \mathrm{~mL} \cdot \mathrm{kg}^{-1} \cdot \mathrm{min}^{-1}\right)$ for 58 days. Exactly 28 days into supplementation, participants took part in $2 \mathrm{~h}$ of running at $60 \% \mathrm{VO}_{2}$ max. Within 20 min of exercise completion, all participants were sensitised to DPCP using a single patch applied to the mid-lower back for $48 \mathrm{~h}$. Following the induction of immune-specific memory (sensitisation), participants reported to the laboratory 28 days later for a dose series of DPCP

\footnotetext{
1 Endurance Research Group, School of Sport and Exercise Sciences, University of Kent at Medway, Chatham, UK.

2 Lincoln Institute for Health, University of Lincoln, Lincoln, UK.

${ }^{3}$ Department of Infection, Immunity and Inflammation, College of Medicine, Biological Sciences and Psychology, University of Leicester, Leicester, UK.

4 Institute of Biological, Environmental and Rural Sciences, Aberystwyth University, Aberystwyth, UK;

${ }^{5}$ University of East Anglia, Norwich, UK.

${ }^{6}$ Extremes Research Group, College of Health and Behavioural Sciences, Bangor University, Bangor, UK.

Email: g.davison@kent.ac.uk
} 
patches to be applied in a randomly allocated order to the volar aspect of their right upper arm for $6 \mathrm{~h}$. Participants returned to the laboratory $24 \mathrm{~h}$ and $48 \mathrm{~h}$ following the application of patches for skin responses (oedema) to be measured at each DPCP patch site using modified skinfold callipers. Standardised diets (for the day pre-trial) and breakfasts (3.5 h pre-trial) were provided. Subjects were provided a $5 \mathrm{~mL} \cdot \mathrm{kg}^{-1}$ bolus of water $20 \mathrm{~min}$ before and immediately after exercise and $2 \mathrm{~mL} \cdot \mathrm{kg}^{-1}$ every 15 min during exercise.

\section{RESULTS}

There was no difference in total oedema responses (sum of all skinfold sites) between COL $(1.84 \pm 1.79 \mathrm{~mm})$ and PLA $(1.01 \pm 0.92 \mathrm{~mm}, \mathrm{p}>0.05)$ at $24 \mathrm{~h}$ or $48 \mathrm{~h}(\mathrm{COL}, 3.36$ $\pm .3 .32 \mathrm{~mm} ; \mathrm{PLA}, 2.83 \pm 1.64 \mathrm{~mm}, \mathrm{p}>0.05)$. Analysis of the dose response curves allowed for the minimum dose (threshold) for a positive response in each group to be determined (i.e. sensitivity). Sensitivity at $24 \mathrm{~h}$ was $0.8 \mu \mathrm{g} \cdot \mathrm{cm}^{-2}$ for PLA compared to $0.4 \mu \mathrm{g} \cdot \mathrm{cm}^{-2}$ for $\mathrm{COL}$, and at $48 \mathrm{~h} 0.7 \mu \mathrm{g} \cdot \mathrm{cm}^{-2}$ for PLA compared to $0.4 \mu \mathrm{g} \cdot \mathrm{cm}^{-2}$ for COL (i.e. greater sensitivity in $\mathrm{COL})$. This was supported by greater oedema response $(p<0.05)$ to the lowest doseresponse dose (which was $\left.1.24 \mu \mathrm{g} \cdot \mathrm{cm}^{-2}\right)$ in COL at $24 \mathrm{~h}$ and $48 \mathrm{~h}(0.22 \pm 0.25 \mathrm{~mm}$ and 0.42 $\pm 0.50 \mathrm{~mm}$, respectively) vs PLA $(0.06 \pm 0.11 \mathrm{~mm}$ and $0.16 \pm 0.19 \mathrm{~mm}$, respectively $)$.

\section{CONCLUSION}

These findings suggest that $\mathrm{COL}$ enhances sensitivity of antigen-specific memory/cellmediated immunity. Although there was no effect on the summed response, there were clear differences at the lowest dose and increased sensitivity in the COL group. Taken together this supports previous evidence from our laboratory where COL has been shown to act as a nutritional countermeasure to the decreased immunity (and increased susceptibility to illness) following prolonged exercise $\left(^{(1,2)}\right.$.

\section{REFERENCES}

1. Davison G, Diment BC. Bovine colostrum supplementation attenuates the decrease of salivary lysozyme and enhances the recovery of neutrophil function after prolonged exercise. British journal of nutrition. 2010 May; $103^{(10)}: 1425-32$.

2. Jones, A.W., Cameron, S.J., Thatcher, R., Beecroft, M.S., Mur, L.A. and Davison, G., 2014. Effects of bovine colostrum supplementation on upper respiratory illness in active males. Brain, behavior, and immunity, 39, pp.194-203. 